\title{
Teaching All Things Evolution
}

\section{Nathan H. Lents*}

Department of Sciences, John Jay College of Criminal Justice, The City University of New York, USA

In the United States, the level of public rejection of the principles of evolution by natural selection has remained alarmingly and stubbornly high. A recent poll indicates that only $40 \%$ of the US population agrees with the statement that human beings evolved from earlier species of animals. Because these principles form the unifying theme of our entire understanding of biological organisms, processes and molecules, its rejection is actually a rejection of science itself. In the face of such anti-intellectual fervor, it is tempting for biologists to throw our hands up and declare that there is little that we can do to change the minds of those so hardened against scientific realities. Nevertheless, we must reject that temptation because indeed there is much that we can and should do.

In the field of biology education, one recent pedagogical strategy that has proven successful in promoting lasting conceptual understanding among students is the use of themes. Most popular in the introductory courses, the use of themes involves the selection of an organism, say, a salmon, a virus, or an oak tree, followed by the teaching of all of the concepts of the course from the perspective of this organism. The learning advantage is that by providing a real and concrete context for all of the principles being learned, these concepts become more apparent, accessible, and relevant, rather than esoteric and mysterious. Especially in our introductory courses which are notoriously jampacked with information, much of the content becomes nothing more than nonsequitors and isolated factettes, with little relevance in the "real world", as students see it. This is the power of the themes, to provide a framework for showing how the content "matters" in the context of the life of an organism.

I would urge that all of us in biology education, from primary school through university, and in all disciplines and courses, should employ the theme of evolution throughout our instruction. This would not replace the use of organism themes described above, but would augment it and provide even further context. After all, we are always saying that evolution is the unifying theme of biology and underpins every detail of the molecules, cells, organisms, and ecosystems on our planet. So why don't we teach it that way? The value of this is two-fold. First, it will help to weave the principles of mutation and selection throughout the concepts, so that students, in a sense, cannot help, but internalize the mechanisms of evolution, which could help combat any pre-loaded cognitive resistance. Secondly, by constantly teaching the "how" and "why" of living systems, and not just the "what," students will actually learn biology better! For example, instead of just teaching the functions of the eukaryotic organelles, we could teach about how they evolved by demonstrating the advantage that early cells would have had, if they began to satisfy its needs through the development and refinement of an organelle. In contrast, it seems silly to teach natural selection as an isolated concept, relegated to a few chapters late in the semester.

The second thing that I urge is that evolutionary biologists and biology educators team up to develop content for teaching biology from this evolutionary perspective. Such content should be carefully designed, rigorously validated, and skeptically analyzed for its impact on not only student comprehension of the relevant biological principles, but also on their grasp of the principles of evolution by mutation, natural selection, and drift. For example, while teaching about the features of eukaryotic genomes, such as coding and noncoding DNA, it might help to better illuminate the topic by showing such sequences in closely versus distantly related species. In so doing, we not only better illustrate the point at hand, we also once again point out that these similarities and differences only make sense in light of the species' shared ancestry.

If we strive to teach all topics through the lens of evolution, we close the door to the feeble intellectual compromises that allow many science students to accept most of what we teach them, while rejecting only "the evolution stuff." We biologists know that biology is "the evolution stuff", and our teaching should make that clear. Together, we can re-write the way that biology is taught from advanced upper-level courses through the K-12 classrooms, by creating and validating exercises for teaching biology by teaching evolution. The Journal of Phylogenetics and Evolutionary Biology eagerly solicits research manuscripts detailing teaching strategies, exercises, and modules, complete with analysis of their validity and effectiveness, that help in the effort of teaching all things evolution.
*Corresponding author: Nathan $\mathrm{H}$. Lents, Ph.D, Department of Sciences, John Jay College of Criminal Justice, The City University of New York, USA, Tel: +646557-4504; E-mail: nlents@jjay.cuny.edu

Received December 27, 2012; Accepted December 31, 2012; Published January 02, 2013

Citation: Lents NH (2013) Teaching All Things Evolution. J Phylogen Evolution Biol 1: e101. doi:10.4172/2329-9002.1000e101

Copyright: (๑) 2013 Lents NH. This is an open-access article distributed under the terms of the Creative Commons Attribution License, which permits unrestricted use, distribution, and reproduction in any medium, provided the original author and source are credited. 